\title{
Review
}

\section{Naming violence: A critical theory of genocide, torture, and terrorism}

\author{
Mathias Thaler \\ Columbia University Press, New York, 2018, 248pp, \\ ISBN: 9780231188142
}

Contemporary Political Theory (2020) 19, S267-S270. https://doi.org/10.1057/s41296019-00347-7; published online 18 September 2019

Liberal political theory has been under significant pressure from realist critics for over a decade. Criticism highlights the aspiration to present theories of justice grounded in moral principles that are in some sense prior to politics. This puts the cart before the horse: if space exists for normative political theory, it must take its cue from the universe of the political itself. In particular, recognition of the fact of political power must precede the moral questions of legitimacy and justice, one way or another.

As Mathias Thaler argues in his brilliant new book, there is much to learn from realism in relation to the ethics of violence. Liberal political thought has extended to the systematic analysis of various permutations of violence in contemporary politics. Violence is treated both as a problem - genocide and terrorism - and sometimes also as part of a solution: for instance, in the form of just war. Thaler thinks the 'moralism' that realists criticize in Rawlsian thought also characterizes contemporary just war ethics as it has been applied to these themes, particularly in the 'revisionist' school.

Thaler's argument focuses centrally on what Mahmoud Mamdani calls 'the politics of naming'. Thaler argues that liberal moralism fails to appreciate the political nature of the concepts on which it relies. Terms like violence, genocide, terrorism and torture are deeply influenced in their shape and extension by hegemonic interests. When liberal ethicists try to isolate theory from these interests by postulating abstract definitions that put concepts beyond contestation, the result, Thaler thinks, is a theory too detached from the realities of political life. But much as he believes philosophers consequently need to learn from realism, Thaler also argues that it necessary to resist realism's excesses. To assume - as some critical terrorism studies scholars do - that naming is entirely determined by political power is to embrace an unwarranted hermeneutics of suspicion. The result is an inability to offer any normative guidance.

(c) 2019 Springer Nature Limited. 1470-8914 Contemporary Political Theory Vol. 19, S4, S267-S270 
What Thaler wants to establish, and I think this is a very valuable contribution, is a via media that he calls 'sober' (as opposed to 'unreconstructed') realism. Sober realism engages in political contestation rather than trying vainly to isolate itself from politics. It mobilizes political concepts for progressive purposes by contesting them in ways that can challenge the influence of powerful interests. Thaler sets out what he calls an 'ameliorative' approach to concepts and the theory that we can build on them, which recognizes two fundamental facts. First, the semantics of terms like 'terrorism' are inseparable from their pragmatic implications - not least due to the feedback loops by which redefining social concepts unavoidably affects the very social contexts to which they refer. Second, no final, authoritative semantic settlement can legislate for the use of these words from a purely philosophical point of view: contestation will continue as long as the terms have a practical salience in public discourse. Premised on these two thoughts, it is, therefore, arguable that ethicists may promote from among the plausible interpretations of key concepts those most likely to help address the problem of violence in a progressive way.

If the grounds for a particular view on something like the concept of genocide are not purely conceptual or factual, then the means of persuading citizens to consider adjusting accepted definitions needn't be purely philosophical either. In the course of a fascinating series of chapters on genocide, torture, and terrorism, Thaler advocates appealing to the imagination to convince people to judge things anew (and to resist cynical attempts to redefine the moral map). Wittgenstein's idea of 'aspect change' describes the shifts that may be possible in the way people see things sitting on or near the conventional borders of categories: things like the plight of climate refugees who suffer harm in ways that are akin to recognized cases of genocide, as he suggests in Chapter 2. This might be brought about by reasoned argument. But public debate may be served better by a more direct appeal to imagination. Thaler offers a powerful argument for the use of film as a medium that puts viewers into a position where it is hard not to see phenomena conventionally placed outside the category of genocide as belonging squarely within it - he uses Jasmila Žbanić's film Grbavica (2006) and Michael Nash's documentary, Climate Refugees (2010), to illustrate film's potential.

Along with the artistic, two other registers of imagination Thaler examines are the hypothetical and the historical. Through genealogy, historical inquiry can disrupt conventional assumptions and open up alternative perspectives on conventional categories. One category with great significance for evaluating political violence is 'innocence'. Thaler favours the idea that 'terrorism' means violence directed intentionally at the innocent but draws on arguments from recent scholarship to highlight the rhetorical and genealogical contexts in which this conception is debated. These bring to light the techniques through which writers attempt or resist redefinitions in public debate and the way in which usages can tacitly carry forward a historical legacy of implicit values and assumptions. 
Thaler explores the register of the 'hypothetical' in relation to torture. But here the relationship between concepts and ethics is different from that found in debates about genocide. Showing that a case meets the description of 'genocide' may be a threshold condition for humanitarian intervention - it's one way that defining a concept can affect action-guidance. But no theorists hypothesize the possibility of a justified genocide. With torture, however, debates about definition are often motivated precisely by the questions of whether and when torture might be justifiable. And hypotheticals are used more often to deal with moral guidance than conceptual clarification: the infamous 'ticking bomb terrorist' hypothetical (itself originating in Jean Larteguy's narrative fiction, The Centurions) is usually invoked to show how torture can be morally necessary in exceptional cases. Sometimes it is used to advocate a practice of torture, as in Alan Dershowitz's argument for torture warrants (pp. 91, 96). But hypotheticals can also reinforce the prohibition against torture by showing how extremely unusual a case would have to be to justify an exception. And philosophers have used it to establish more general claims: for instance, in Michael Walzer's account of dirty hands (1973). But, whichever the aim, the hypothetical is invoked to persuade readers that torture could be permissible in that set of circumstances.

Thaler's argument is that hypotheticals are themselves subject to something like a code of ethics. Some ways of using them are morally and methodologically suspect. One criterion for evaluating them has to do with modality. Thaler distinguishes hypotheticals that are possible simpliciter from those that are possible in the world as it is now (p. 107). These do not entirely map onto the impermissible and the permissible, respectively (p. 111), but the modal detachment from lived reality of the former nevertheless increases the risk that they will disorientate readers rather than inform them. Properly used, realistic hypotheticals are more apt to help us to rethink accepted wisdom in useful ways. More significant, perhaps, is the idea of framing. Thaler draws on Susan Sontag and Judith Butler to show how hypotheticals can exclude some individuals from proper moral attention, putting them beyond readers' or listeners' capacity to sympathize. In the ticking bomb story, for instance, the terrorist's suffering is eclipsed by the plight of the bombing victims which frames it out of the grievable space that the hypothetical defines (p. 105).

Hypotheticals should help 'navigate the complex moral universe we currently inhabit', paying due regard both to modality and to the claims on humanity of all persons affected (p. 111). Given these criteria, I wonder what hypotheticals could probe the ethics of torture without falling foul of Thaler's framework. Typically, torture hypotheticals are similar to those used in just war theory, asking us to imagine occupying a position where we have only bad choices: use (cruel or lethal) violence against the attackers, or do nothing and let people be killed. Revisionists use these thought experiments to show how, when someone forces these dilemmas on others, it can render her liable to be harmed in resolving them. This, presumably, is the point at

(C) 2019 Springer Nature Limited. 1470-8914 Contemporary Political Theory Vol. 19, S4, S267-S270 S269 
which the framing of a hypothetical might be thought to exclude that person's humanity. If so, then one reply is to maintain that it's not the hypothetical that's the problem, but the idea of liability. Liability implies not being wronged when subjected to defensive force, hence not having a claim on anybody's moral indignation when you suffer necessary, proportionate harm. A just war revisionist might argue that hypotheticals don't generate this possibility: used carefully, they help to illustrate it. If judging someone to be liable to harm in some way reduces our sympathy with that person, then this is itself part of the moral reality of life.

Perhaps, then, Thaler's argument points towards the need not to avoid hypotheticals that present people as liable to force, but to use more hypotheticals from different perspectives. For instance, it might be necessary not only to hypothesize from the perspective of the ticking bomb victims or their political representatives, but also from that of the bombers. By putting ourselves in their position, we might appreciate better the moral choices through which they came to find themselves in the ticking bomb story - and this might go some way towards 'giv[ing] prominence to the dignity of victims [i.e. of defensive force], no matter who they are or what they have done' (p. 113). Arguably, Jeff McMahan does this when he evaluates the mitigating factors that diminish the responsibility, hence the liability of 'unjust warriors' (McMahan 2009, ch. 3). But Thaler's argument provides a much needed critical account of the reasons why this is something that analytical ethicists should generally do systematically.

Philosophers and political theorists working on the ethics of violence should pay close attention to Thaler's fine book. Its promising synthesis of realism, critical theory and ethics shows how important the politics of naming is for the morality of violence and points out ways to take account of it without losing sight of the need for normative guidance.

\section{References}

McMahan, J. (2009) Killing in War. Oxford: Clarendon Press.

Walzer, M. (1973) Political Action: The Problem of Dirty Hands. Philosophy \& Public Affairs 2(2): $160-180$.

Publisher's Note Springer Nature remains neutral with regard to jurisdictional claims in published maps and institutional affiliations.

Christopher Finlay

Durham University, Durham DH1 3LE, UK christopher.j.finlay@durham.ac.uk

S270 (c) 2019 Springer Nature Limited. 1470-8914 Contemporary Political Theory Vol. 19, S4, S267-S270 